\title{
An Exploratory Study on the Electronic Word of Mouth Communication in Promoting Brands in the Online Platforms
}

\author{
B. N. Malar Selvi*, J. Edwin Thomson \\ Department of Management Studies, Vels University, Chennai - 600 117, Tamil Nadu, India \\ Email: ‘bn.malarselvi@nift.ac.in, jetecoguru57@gmail.com
}

How to cite this paper: Malar Selvi, B.N. and Edwin Thomson, J. (2016) An Exploratory Study on the Electronic Word of Mouth Communication in Promoting Brands in the Online Platforms. Intelligent Information Management, 8, 115-141. http://dx.doi.org/10.4236/iim.2016.85010

Received: July 25, 2016

Accepted: September 27, 2016

Published: September 30, 2016

Copyright $\odot 2016$ by authors and Scientific Research Publishing Inc. This work is licensed under the Creative Commons Attribution International License (CC BY 4.0).

http://creativecommons.org/licenses/by/4.0/

\begin{abstract}
This study discusses on the communication method followed by most of the brands called. "Electronic Word of Mouth" in a short form is called as eWOM in order to reach the customers effectively in a short span. Social media having become a new hybrid component of integrated marketing communication allows the brands to establish strong relationship with the customers. With the establishment of customer relationship online, the brands create a platform for the customers to discuss about the product features, quality, price and write a review about the product online. This research analyses about the social media and its impact in spreading the messages about the brands to the end customers and the impact of gender, age groups, income, designation and the demographic details of the customers in trusting the information that is spread through electronic media and the level at which the eWOM helps the customers to select the brand.
\end{abstract}

\section{Keywords}

Word of Mouth, Integrated Marketing Communication, Customer Relationship

\section{Introduction}

In today's world, technology has significantly changed the lifestyle of people. Our daily behavior of people is driven by the technology and consumers' behavior is no exception. Consumers have more information available to them like never before and expect information to be available whenever they want it. Moreover, they access and utilize this information in increasingly different mediums and with different motivations. Social media is [1] "A group of Internet-based applications that build on the ideological and technological foundations of Web 2.0, and that allow the creation and exchange of 
User Generated Content". Social media encompass a variety of online informationsharing formats including social networking sites (SNSs) like Facebook, MySpace and Friendster, creativity works-sharing sites like YouTube and Flickr, collaborative websites like Wikipedia and micro blogging sites like Twitter.

The arrival of social media has created a two-way and many-to-many communication system allowing consumers to connect, create, produce, and share media content in media platforms like Facebook, YouTube, Twitter, Pinterest, etc. These Web 2.0 properties have helped to transform consumers from inactive observers to active participants with social media serving as an ideal platform for brands related electronic word-of-mouth. Word Of Mouth is considered to be one of the most influential factors impacting consumer decision-making at all phases; from initial product awareness to product choice to post-purchase evaluations.

Marketer-generated information consists of traditional advertisements such as TV commercials, radio commercials, or ads on the Internet. User-generated information consists of conversations between customers and in these conversations, the information, is both produced and consumed by customers. User-generated information simply refers to the word of mouth (WOM), which is informal communication between people regarding the products and services of a company. Word of mouth has gained a new dimension in the age of the Internet. The Internet has facilitated this form of communication by providing ever-increasing space for consumers to share personal opinions and experiences. This new form of exchange is called electronic word of mouth (eWOM).

\section{Electronic Word-of-Mouth}

Electronic word of mouth is more influential than traditional WOM for several reasons. First, with the development of the Internet and various electronic media, messages can be quickly spread to reach a potentially large audience. Second, recipients of the messages actively seek a broader range of comments online and therefore do not rely only on the opinions of acquaintances.

Third, eWOM can be accessed immediately or after a period of time; its digital footprint can remain online permanently. Fourth, secrecy encourages people to publish reviews online knowing they cannot be identified. Finally, eWOM communication enables an individual to build up personal and social networks. As opinions reach friends as well as strangers via the Internet, it is essential for brands to understand what motivates customers to produce eWOM in order to promote their products better and prevent negative publicity.

Digital communication is used more frequently when compared with face-to-face communication, and customers are embedded daily with hundreds of messages regarding products and services from a variety of sources classified as either marketer-generated or user-generated.

\section{Literature Review}

The following literature review addresses four areas: 1) eWOM its consequences in so- 
cial networking sites; 2) eWOM Motivation framework; 3) Consumer's attitude and behavior; 4) Impact of Gender based decision in eWOM.

\section{1. eWOM}

In contrast to traditional word of mouth communication, Electronic Word of Mouth is defined as "any positive or negative statements made by potential, actual, or former customers about a product or company, which is made available to a multitude of people and institutions via the Internet' [2]. Such statements tend to travel quicker because of their venue and are relatively permanent in nature and come at a minimal search cost to potential recipients.

Seekers of eWOM are interested in reducing risk, securing lower prices and having easy access to information prior to purchase decisions. eWOM is often unsolicited by recipients and unintentionally attended to. Various studies connect the influence of eWOM with Brand reputation, Brand trust and product attitudes, consumer decision-making, e-commerce sales and cross cultural differences. Research in this area tends to focus on one of three areas [3] structure and format, function and purpose and recipient impact.

Also identified two major types of context for eWOM. The first type of eWOM is information oriented which consists of websites such as consumer review forums and product feedback pages. Reviews in such contexts tend to be specifically focused on product performance. A second type of eWOM context is emotion-oriented and includes non-product focused online communities and social networks. Here, consumer reviews tend to emphasize broader product experiences, which are more subjective in nature.

Social networks are defined as "virtual communities created for people to connect with others by means of popular web-based tools". These tools are often Web 2.0 applications that allow for the creation and exchange of consumer-generated content within Journal of Marketing Communications 85 social networks constructed around software platforms, commonly characterized as social media. The implications for the exchange of brand-related consumer-generated information are important because research suggests that eWOM recipients trust their network peers and even the opinions of people outside their network.

\subsubsection{Transition of Word-of-Mouth (WOM) to Electronic Word-of-Mouth (eWOM)}

Word-of-mouth (WOM) dates back to the oral tradition, existing from the time that people began engaging in conversation. Defined as "oral, person to-person communication between a perceived noncommercial communicator and a receiver concerning a brand, a product, or a service offered for sale", these informal conversations between consumers have been found to have a significant impact on consumer choice and to be more effective than traditional marketing tools. The advent of the Internet introduced a new form of word-of-mouth, called electronic word-of-mouth, also known as eWOM, that exists online and allows consumers, who are typically strangers, to interact with 
one another and share their opinions about various goods and services. This consumer-to-consumer communication has become increasingly influential in consumers' purchasing decisions and has shifted the power of influence from marketers to consumers, as today's consumers are no longer passive receivers of product related information but rather active communicators who seek fellow consumers' opinions and offer their own. eWOM is differentiated from traditional WOM in several ways.

- Traditional word-of mouth involves spoken, person-to-person communication, whereas eWOM is not face-to face communication but rather the passive reading of a computer screen or active writing of a message.

- Traditional WOM takes place privately and conversations are perishable; eWOM takes place publicly online, on platforms such as blogs, review sites and social networking sites, and, because it is written, is stored for future reference. Because eWOM is defined as taking place publicly online and being delivered to a multitude of people via the Internet, it does not include one on-one conversations that may take place online, for example, via email, Skype or instant message.

- The most basic forms of internet-based communication, email and instant messaging (IM), are essentially one-on-one channels that exist separately from any related web-based content or information. Newer forms of internet communication facilitated by blogs, forums, and social networking sites depart from the email model 8 in two key ways: They provide a channel for one person to reach many others, and they are increasingly associated with specific topics.

- Another distinction between WOM and eWOM is the reach of the communication that occurs with eWOM, achieved through the Internet's low-cost, bi directional communication capabilities. Various eWOM platforms, such as online discussion forums, blogs, review sites and social networking sites, allow for multi-way exchanges in an asynchronous mode, resulting in "unprecedented scalability and speed of diffusion".

- "Conventional marketing wisdom has long held that a dissatisfied customer tells ten people. But that is out of date. In the new age of social media, he or she has the tools to tell 10 million".

- Although eWOM may create more influence than traditional WOM due to its viral nature and reach and because its online existence allows access to information whenever the user seeks it out, it is also significantly less personal than traditional WOM, which may lessen its impact.

- Unlike traditional WOM, which takes place between individuals familiar with each other, eWOM can include both identified and unidentified sources of information most WOM involves individuals known and trusted by the receiver, such as family and friends, as well as perceived experts, whereas eWOM typically involves individuals who are strangers with no indication of expertise about the product category at hand.

- Despite the unprecedented volume and reach of eWOM, its effects have been found to be less influential than traditional word-of-mouth in decision-making for 
high-risk and complex purchases, such as travel. Word of mouth of friends, family and acquaintances affects tourist behavior to a larger degree than communication with other Internet users, whether these users are known to the tourist or not.

\subsection{2. eWOM and Social Networking Websites}

The widespread popularity of the Internet and its increasing use worldwide has focused attention on eWOM as a marketing tool in terms of both the academic and business context. The main point in this concept is to create opportunities for customers to exchange ideas and notions regarding the products and services of companies. This kind of information has been considered vital because of its influence on consumers ' purchase intentions. Because of the speed and convenience of the Internet, customers can acquire eWOM information instantly with just a few clicks from different types of sources, such as blogs, review websites, and online discussion forums.

Social networking websites are another sort of online source providing available space for eWOM. Through social media, consumers have the [4] opportunity to talk about products, services, and their purchase decisions with their friends. Although social networking websites have a similar aim-which is to make connections between people-the way they connect people is different. For example, Twitter allows only short posts with a limit of 140 characters, whereas YouTube focuses mainly on videos. Facebook, on the other hand, has no limitations or specific focus on any type of posting. This variety in content causes social networking websites to have different customer engagement ratios.

According to the report on [5] Facebook mobile users as of March 31, 2014 alone is 1.01 billion, number of Facebook users in India alone is over 100 Million, there are more than 50 million Facebook pages, $75 \%$ of the engagement on a post happens in first 5 hours. Twitter users tweet 500 million "tweets" per day. Consumers spend a monthly average of 89 min on Twitter and 405 min combined on Facebook and Pinterest [6]. Meanwhile, Pinterest is the fastest social media platform to achieve 10 million unique visitors, used by 100 plus brands, and is driving more referral traffic (i.e., eWOM) to retailers than LinkedIn, YouTube, and Google plus [7]. Ultimately, one must wonder how consumers are capable of processing any information within such a saturated media environment. Of course, the answer is selective attention, which is a critical factor to consider in the context of consumer-generated eWOM.

\subsubsection{Social Media as a Channel for eWOM}

The creation and exchange of electronic word-of-mouth is facilitated through social media, defined as "a group of Internet-based applications that build on the ideological and technological foundations of Web 2.0, and that allow the creation and exchange of User Generated Content" [8]. Social media serve as the channel by which eWOM the message is delivered to consumers, providing platforms for people to express their opinions on products, companies and brands. Although eWOM literature states the different types of social media that eWOM exists on (e.g., blogs, review sites, e-mail, etc.), few studies have specifically examined the influence of eWOM when consumed across 
different social media platforms. Research singled out social networking sites (SNS) as a natural platform for eWOM to take place because of its inherent social aspect [9].

\subsection{Consumer's Attitude and Behavior}

Consumers feel more engaged with companies when they can share their opinions and experiences about products or services; and social networking websites are very appropriate platforms for this engagement. For this reason, researchers have a growing interest in the relationship between these websites and customer engagement. Marketers try to define and to build their engagement methods, because these websites are important tools to manage their relationships with customers. Many social networking websites have different features to indicate customer engagement. For companies that create posts to promote their products and services, the most prominent indicators are the number of "likes", the number of "shares", and the number of "comments". These numbers also express how the information inside the post spread among customers through eWOM. Although the aim is similar, customer engagement opportunities provided by these websites are not entirely the same. Some have greater customer engagement ratios than others. The current study examines these ratios for the benefit of both marketers and researchers.

The behavior among various types of people differs, of course [10]. Two specific types of people: those motivated by promotion and those motivated by prevention. Regulatory focus is the term given to the way in which people seek pleasure to avoid pain and therefore may focus their attitudes in prevention (to avoid pain) or promotion (to get pleasure).

Those who are focused on promotion aim more toward a goal that is to be achieved, highlighting the possible gains, while those who are focused on prevention seek to avoid losses/damages and value safety. Regulatory focus influences the definition of a person's expectations, as well as the determination of his or her goals and strategies. Someone with a focus on promotion seeks to maximize gains in a situation. If the focus is on prevention, he or she tends to prevent losses. The effectiveness of comment management is likely to increase if the message conveyed by a company to the consumer is consistent with his or her regulatory focus. It is expected, therefore, that the content of the reply message to consumers' negative comments on the Internet will have different effects according to the regulatory focus (promotion or prevention) of the receptor.

In this way, two more hypotheses follow: H7: A response of promotional content from a company further reduces the impact of negative comments, posted by consumers on the Internet, on the brand image as perceived by those other consumers (exposed to both comments and responses) who are focused on promotion, as opposed to those who are focused on prevention.

H8: A response of promotional content from a company further reduces the impact of negative comments, posted by consumers on the Internet, on the purchase intention of other consumers (exposed to both comments and responses) who are focused on promotion, as opposed to those who are focused on prevention. 


\subsection{Motivation Framework of eWOM}

Researchers have explained eWOM from various disciplines, including psychology, sociology, economics, and political science. In this study, the authors introduced three types of utilities that motivate people to leave their opinions online: The focus-related utility (e.g., comes from adding value to the community), consumption utility (e.g., comes from individual's consumption of contributions from others), and approval utility (e.g., comes from the approval from others) [11]. Four motivations for eWOM: social interaction benefits/self enhancement, helping the company (or brand), vengeance upon the company, concern for others, and economic incentive [12]. The research enriched by introducing the concept of the public good (i.e., collectivism, egoism, altruism, and principals), knowledge, and self-efficacy. Most literature emphasizes the impact of eWOM communication, explores the process and motives of eWOM communication, and tries to identify how the communication influences the customer purchase decision.

\section{Six Motivational Factors for eWOM Communication}

Self-expression is defined as a means that enables a speaker to express his or her certain emotional needs. It combines self-involvement with product involvement, wherein an individual can fulfill an emotional need to express opinions about a product that generates intense feelings. Consumers can achieve several goals through eWOM communication, such as seeking post-purchase advice, expressing successful purchase experience and gaining approval from other consumers.

Vengeance upon the company is characterized as a desire to retaliate against a company that provided the consumer with a negative experience. A similar term, venting negative feelings, is defined as a way to ease frustration. Vengeance upon the company and venting negative feelings are both generated through an unsatisfactory experience but they differ in that the former describes a revenge behavior targeting a particular company or product, while the latter is merely a consumer expressing frustration toward a company or product. In other words, a desire for catharsis is taken as a primary motivation for this online negative emotion relief.

Concern for others comes from the desire to perform the altruistic act of helping another consumer make an informed purchase decision, which can cause both positive and negative WOM. Consumers motivated by a concern for others provide eWOM communication as a way to use their experience, either positive or negative, to help friends and strangers alike achieve maximum benefit.

Overall trust and distrust are related eWOM motivations, in that they are both built on the relationship between an information provider and an information seeker. Trust refers to the "willingness of a trust or to be vulnerable to the actions of a trustee, according to the expectation that the trustee will perform a particular action important to the trust or". Most current research discusses the issue of trust since it has a significant impact on consumer buying behavior. However, in this paper, trust and distrust are characterized by new motivations that explain why consumers share information Online. 


\subsection{Impact of Gender Based Decision}

Men and women often face conflict and communication differently. Some of this can be attributed to the different values that are important to different genders. Walter Ong [13] asserted that men are inclined to live comfortably with conflicts and disputes; he wrote, "Conspicuous is a larger element in the lives of males than of females".

Additionally, men's lives often naturally involve combat, struggle, contention, and competition because status and placement within a hierarchy can be altered through conflicts and debate. Women, on the other hand, often prefer to solve problems in more private ways, but will occasionally employ an intermediary to resolve oral disputes. Given this, men may be motivated to discuss conflicts with a company through eWOM communication to boost their status.

Men view the world as a hierarchy and therefore, in order to achieve desired status, men seek out autonomy and respect. Women tend to view the world differently; they see it as a network, which explains the high value women place on intimacy and relationships [14]. Tannen's findings help explain the female tendency to form a group, where all members are treated equally without competition, and the male preference for forming a group with complex rules to determine status. Therefore, women, who often strive to form alliances and equal status with peers, may care about others more than men.

WOM has a strong impact on women because women are inclined to embrace the opinions of someone similar and often rely on other people's impressions about products and services. They often seek advice from product review platforms when making a purchase decision. Additionally, many women like to act in a way that creates a benefit for the community, and seek to receive trust from that community.

On the Internet, much like in real-life, women seek to obtain social support through cooperation and network-oriented collaboration. Men however, often use the Internet to improve and build social status by challenging, debating or arguing the opinions others express online.

Accordingly, we assume that women tend to provide eWOM communication because they trust the reviews and feel that they can receive trust back by sharing information. Similarly, men may be less inclined to trust the reviewer and more inclined to provide eWOM communication in order to challenge the information provider.

\section{Research Methodology}

Research comprises defining and redefining problems, formulating, hypothesis or suggested solutions; collecting, organizing, evaluating data; making deductions and reaching conclusions; and at last carefully testing the conclusions to determine whether they fit the formulating hypothesis.

[15] Research is defined research as "the manipulation of things, concepts or symbols for the purpose of generalizing to extend, correct or verify knowledge, whether that knowledge aids in construction of theory or in the practice of an art".

Research is thus an original contribution to the existing stock of knowledge making for its advancement. It is the pursuit of truth with the help of study, observation, com- 
parison and experiment.

Research methodology process includes a number of activities to be performed. These are arranged in proper sequence of timing for conducting research. One activity after another is performed to complete the research work. Research methodology includes the following.

\subsection{Objectives}

1) To understand what is Electronic Word of Mouth Communication (eWOM).

2) To analyze the impact of Gender on eWOM communication.

3) To study how eWOM communication method influences the purchase decision of the consumers.

\subsection{Research Design}

Descriptive research includes surveys and fact finding enquiries of different kinds. The major purpose of descriptive research is description of the state of affairs as it exists at present.

The methods of research utilized in descriptive research are survey methods of all kinds, including comparative and correlational methods. In analytical research, on the other hand, the researcher has to use facts or information already available and analyze these to make a critical evaluation of the material.

\subsection{Data Collection}

\subsubsection{Questionnaire}

A set of questions has been prepared to ask and collect answers from respondents related to the research topic. The number of questions were in printed and electronic form which the individuals had to answer. These set of questions are asked to individuals to obtain statistically useful information on the given topic. They have been selected randomly. So stratified convenient sampling has been used for the study. Keeping in view the proper representation of every segment of population and manageable size of the sample, the sample size selected is 200 .

\subsubsection{Statistical Tools for Data Analysis}

For data analysis and testing of hypothesis Independent $\mathrm{T}$ Test and Chi-square test will be used.

\subsubsection{Data Sources}

For the study purpose both primary and secondary data are used. Primary data are original in nature and directly related to the issue or problem and current data. The primary data collected from experts in social media platforms, CEO's of social media platforms and the population of Bangalore (Men and Women).

The secondary data collected from journals, articles, social media platform of Brands, retailers, fashion designers and e-commerce platforms. The census data from score rating agency is also taken. The primary and secondary data have been collected to cover 
every aspect of the study.

\subsubsection{Sampling}

a) Introduction

The research is a systematic study to examine or investigate the issue or problem and find out the relevant information for solution. For study data are to be collected from the respondents. It is not possible to collect data from every one of the population. Population is a very large number of persons or objects or items which is not feasible to manage.

A population is a group of individuals, persons, objects, or items from which samples are taken for measurement. For research purpose a part of the population is to be selected. Sampling is the process in which a representative part of a population for the purpose of determining parameters or characteristics of the whole population is selected. This is called a sample.

b) Population

For this research study purpose out of different sampling methods the stratified Random sampling has been selected. The study includes respondents located in different parts of Bengaluru city. Out of Bengaluru city main areas like Malleshwaram, Marathahalli, Jayanagar, M.G. Road, ITPL, Yeshwanthpura and Koramangala have been selected.

\subsubsection{Data Analysis from Questionnaire}

Table 1. Gender of the respondents.

\begin{tabular}{cc}
\hline Gender & No. of respondents \\
\hline Female & 98 \\
Male & 102 \\
Total & 200
\end{tabular}

As per the survey and as shown in the Table 1 and Figure 1, both female and male respondents are with equal half percentage of $49 \%$ and $51 \%$ of the total sample group.

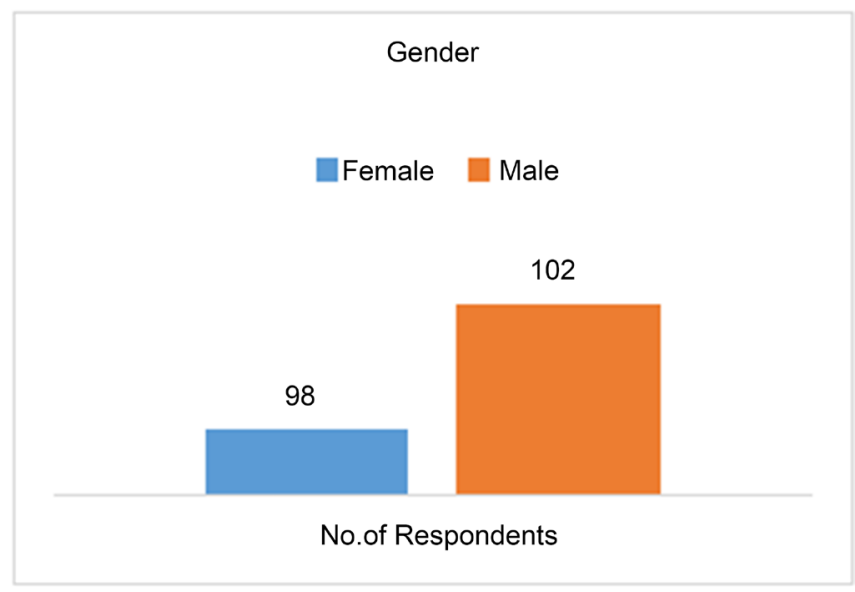

Figure 1. Gender of the respondents. 
Table 2. Location of the respondents.

\begin{tabular}{cc}
\hline Location & No. of respondents \\
\hline ITPL & 29 \\
Jayanagar & 32 \\
Koramangala & 33 \\
M. G. Road & 31 \\
Malleshwaram & 31 \\
Marathahalli & 20 \\
Yeshwanthpura & 24 \\
Total & 200 \\
\hline
\end{tabular}

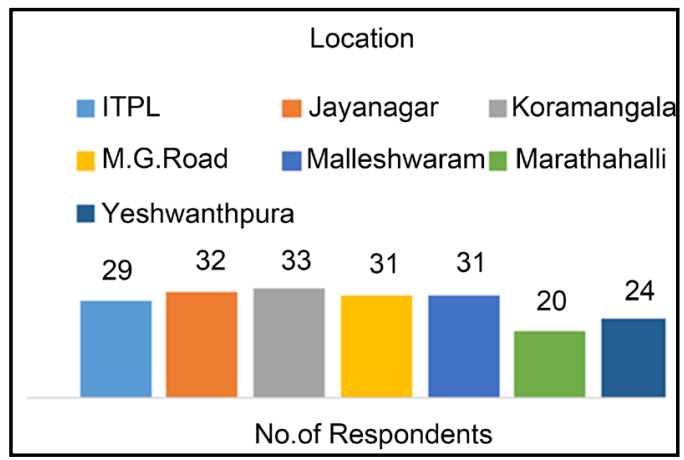

Figure 2. Location of the respondents.

From Table 2 and Figure 2, it is evident that, all the major places of Bangalore city had an average of $28 \%$ respondents each.

Table 3. Age of the respondents.

\begin{tabular}{cc}
\hline Age & No. of respondents \\
\hline Below 20 yrs & 22 \\
$20-25$ yrs & 40 \\
$26-30$ yrs & 52 \\
$31-35$ yrs & 44 \\
$36-40$ yrs & 13 \\
Above 40 yrs & 29 \\
Total & 200 \\
\hline
\end{tabular}

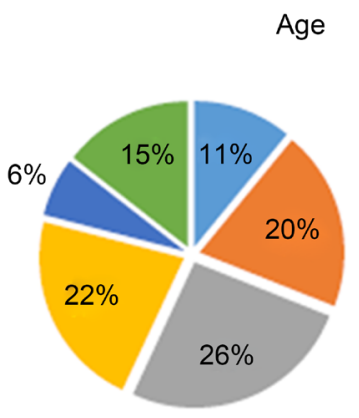

Below 20yrs

20-25yrs

$26-30 y r s$

$31-35 y r s$

$36-40 y r s$

Above 40yrs

Figure 3. Age of the respondents. 
In this survey, according to above Table 3 and Figure 3, there are more respondents with age group between 26 - 30 years $26 \%$ and next the age group between 31 - 35 years with $22 \%, 20$ - 25 years with $20 \%$, above 40 years with a $15 \%$ and remaining with $17 \%$ of the total respondents.

Table 4. Average income/month of the respondents.

\begin{tabular}{cc}
\hline Avg. income/month (Rs.) & No. of respondents \\
\hline Nil & 39 \\
Below 30,000 & 34 \\
$30,000-50,000$ & 79 \\
50,000 and above & 48 \\
Total & 200 \\
\hline
\end{tabular}

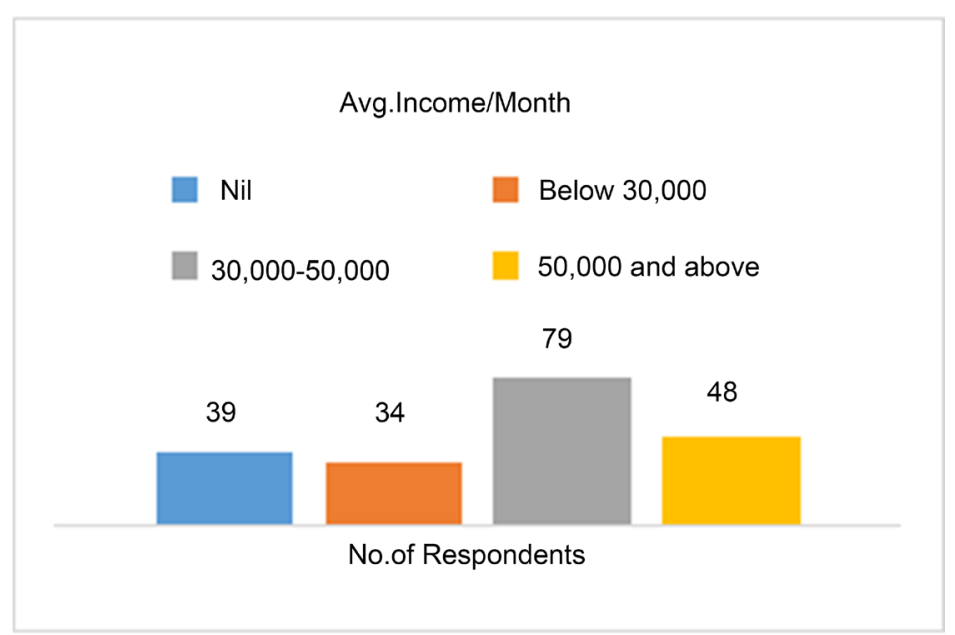

Figure 4. Average income/month of the respondents.

It could be inferred from the above Table 4 and Figure 4 that $40 \%$ of the respondents fall under the income category of Rs 30,000 - Rs 50,000, $24 \%$ fall under the income category of Rs 50,000 \& above, $20 \%$ have not reached the earning stage and the remaining $17 \%$ earn below Rs 30,000.

Table 5. Internet usage/day of the respondents.

\begin{tabular}{cc}
\hline Usage of internet/day & No. of respondents \\
\hline $1-5 \mathrm{hrs}$ & 27 \\
$11-15 \mathrm{hrs}$ & 56 \\
$6-10 \mathrm{hrs}$ & 81 \\
$16-24 \mathrm{hrs}$ & 36 \\
Total & 200 \\
\hline
\end{tabular}




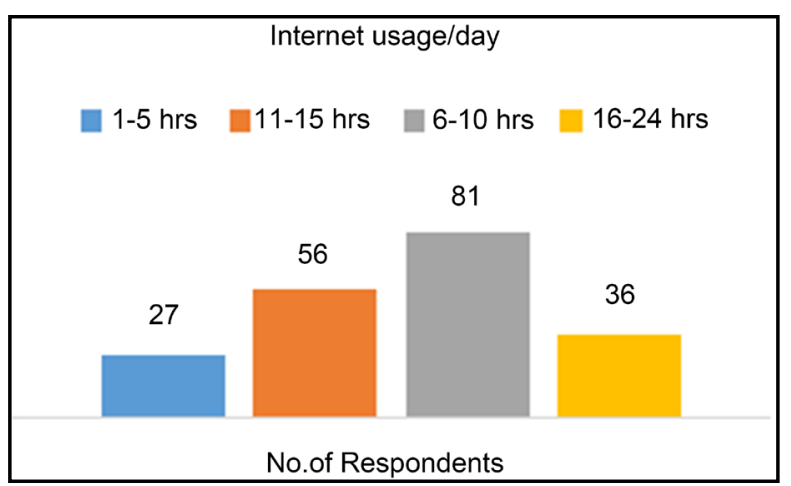

Figure 5. Internet usage/day of the respondents.

It is evident from the above Table 5 and Figure 5 is shown that $41 \%$ of the respondents use internet $6-10 \mathrm{hrs} /$ day, $28 \%$ use internet $11-15 \mathrm{hrs} /$ day, $18 \%$ use internet 16 - $24 \mathrm{hrs} /$ day, $14 \%$ use internet at minimum hours of $1-5 \mathrm{hrs} /$ day.

Table 6. Read online reviews before buying an item.

\begin{tabular}{cc}
\hline Read online reviews before buying an item & No. of respondents \\
\hline Always & 145 \\
Sometimes & 48 \\
Never & 7 \\
Total & 200 \\
\hline
\end{tabular}

Online Reviews before buying an item

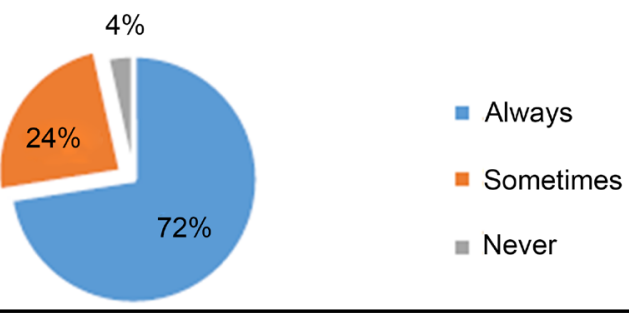

Figure 6. Read online reviews before buying an item.

The above Table 6 and Figure 6 it is proved that $72 \%$ of the respondents always read online reviews before purchase, $24 \%$ of them sometime read reviews and $4 \%$ don't read any online reviews before the purchase.

Table 7. Online review helps in decision making.

\begin{tabular}{cc}
\hline Online reviews helps in decision making & No. of respondents \\
\hline Always & 135 \\
Sometimes & 52 \\
Never & 13 \\
Total & 200 \\
\hline
\end{tabular}




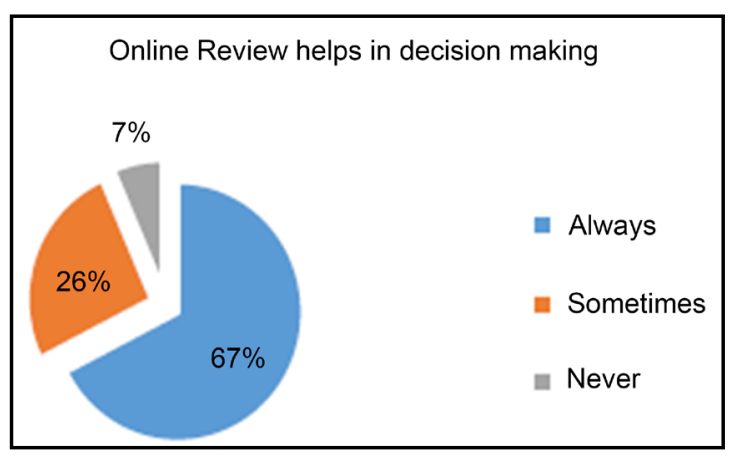

Figure 7. Online review helps in decision making.

The above Table 7 and Figure 7, it is proved that online reviews are always helpful in decision making for $67 \%$ of the respondents, $26 \%$ of them sometime take decisions and $7 \%$ don't relay on online reviews for decision making.

Table 8. Positive online reviews, affects the purchase choice positive.

\begin{tabular}{cc}
\hline Positive online reviews, affects my purchase choice & No. of respondents \\
\hline Agree & 179 \\
Disagree & 11 \\
Neutral & 10 \\
Total & 200 \\
\hline
\end{tabular}

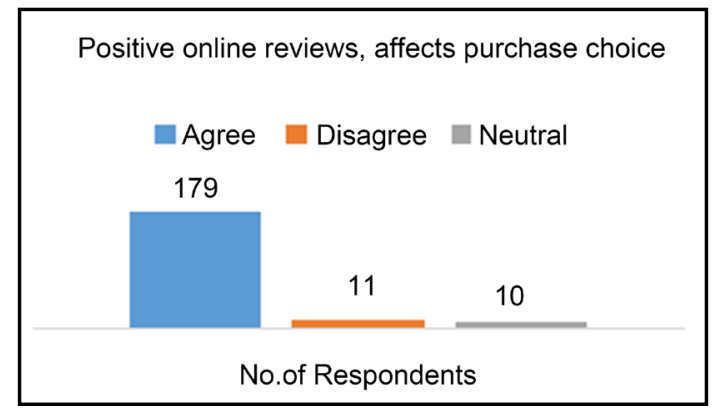

Figure 8. Positive online reviews, affects the purchase choice positive.

It is highly evident from the above Table 8 and Figure 8 , it is shown that $90 \%$ trust on the positive reviews in consideration with their buying decision.

Table 9. Negative online reviews, affects the purchase choice.

\begin{tabular}{cc}
\hline Negative online reviews, affects the purchase choice & No. of respondents \\
\hline Agree & 184 \\
Disagree & 7 \\
Neutral & 9 \\
Total & 200 \\
\hline
\end{tabular}




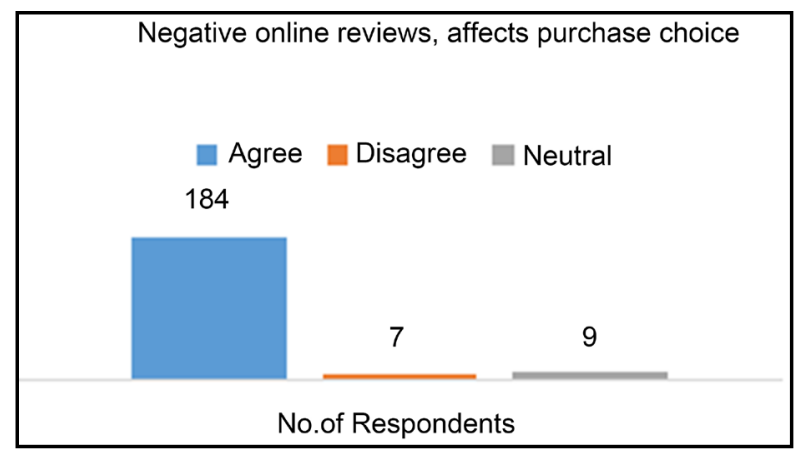

Figure 9. Negative online reviews, affects the purchase choice.

It is highly evident from the above Table 9 and Figure 9 is shown that $92 \%$ trust on the negative reviews in consideration with their buying decision.

Table 10. High product ratings, affects the purchase decision.

\begin{tabular}{cc}
\hline High product ratings, affects the purchase decision & No. of respondents \\
\hline Always & 103 \\
Sometimes & 93 \\
Never & 4 \\
Total & 200 \\
\hline
\end{tabular}

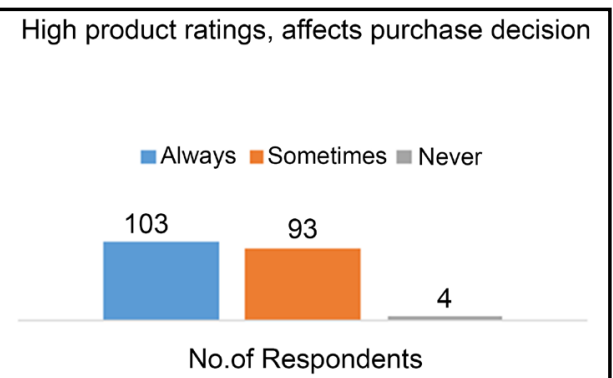

Figure 10. High product ratings, affects the purchase decision.

The above Table 10 and Figure 10, it is shown that the number of ratings from 1 - 5 affects the buying decision always with $52 \%$ and sometimes with $47 \%$ and never with $2 \%$ of the total respondents.

Table 11. Write positive reviews for a product you purchased and felt satisfied.

\begin{tabular}{cc}
\hline Write positive reviews for a product & No. of respondents \\
\hline Always & 38 \\
Sometimes & 89 \\
Never & 73 \\
Total & 200 \\
\hline
\end{tabular}




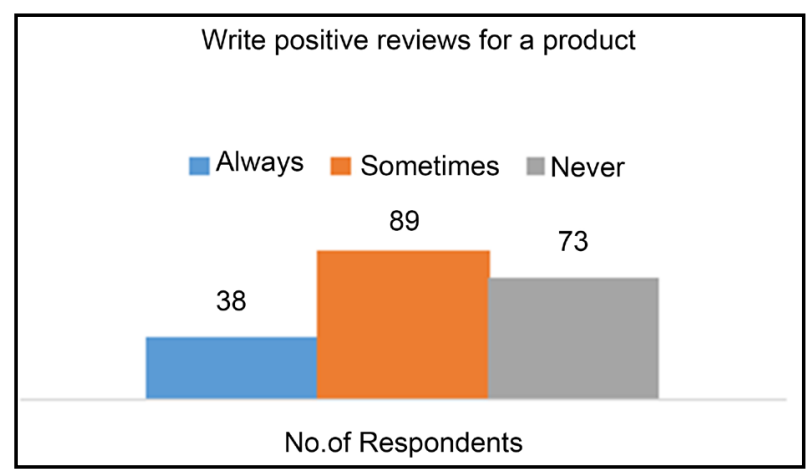

Figure 11. Write positive reviews for a product you purchased and felt satisfied.

It is inferred from the above Table 11 and Figure 11, it is referred that writing positive reviews for a happily purchased product is highly $45 \%$ sometimes, and remaining $56 \%$ of the respondents always and never write.

Table 12. Write negative reviews on a company that harmed you/gave the wrong item.

\begin{tabular}{cc}
\hline Write negative reviews on a company that harmed you/gave the wrong item & No. of respondents \\
\hline Always & 31 \\
Sometimes & 85 \\
Never & 84 \\
Total & 200
\end{tabular}

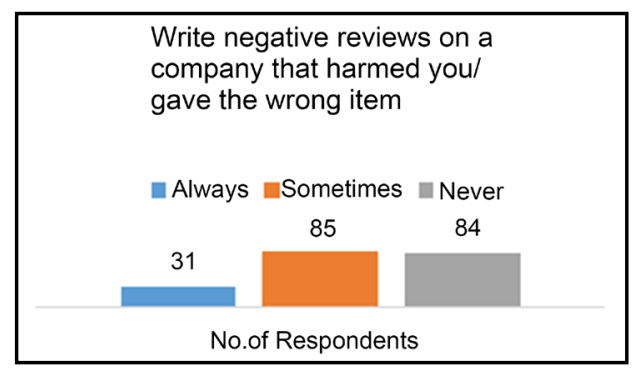

Figure 12. Write negative reviews on a company that harmed you/gave the wrong item.

The above Table 12 and Figure 12, it is shown that $16 \%$ of the total respondents always write negative reviews on the company that harmed them, remaining $85 \%$ never write or sometimes write negative reviews.

Table 13. Write reviews to save friends/colleagues from purchasing a bad product.

\begin{tabular}{cc}
\hline Write reviews to save friends/colleagues from purchasing a bad product & No. of respondents \\
\hline Always & 131 \\
Sometimes & 53 \\
Never & 16 \\
Total & 200
\end{tabular}




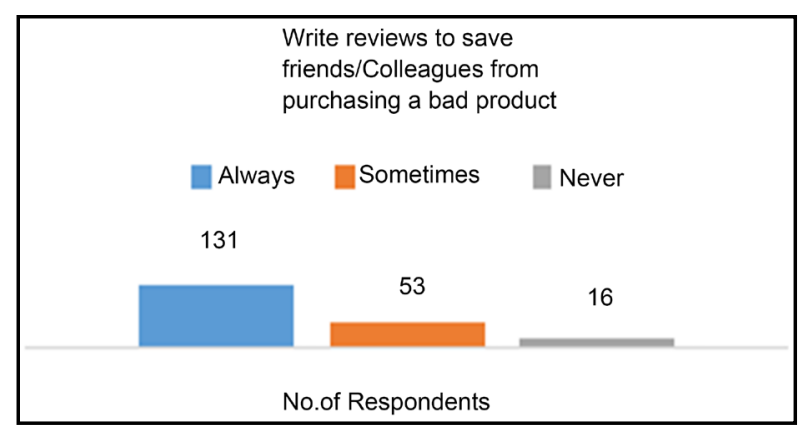

Figure 13. Write reviews to save friends/colleagues from purchasing a bad product.

The above Table 13 and Figure 13, it is shown that $66 \%$ of the total respondents always write online reviews to save their friends/colleagues, whereas $27 \%$ sometimes write, leaving only $8 \%$ least bothered about their neighboring.

Table 14. Customer reviews online are trustworthy/dependable.

\begin{tabular}{cc}
\hline Customer reviews online are trustworthy/dependable & No. of respondents \\
\hline Always & 93 \\
Sometimes & 90 \\
Never & 17 \\
Total & 200 \\
\hline
\end{tabular}

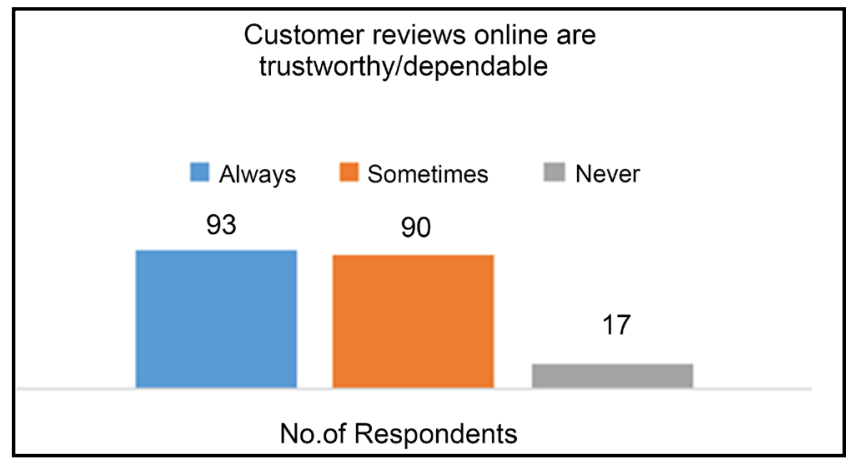

Figure 14. Customer reviews online are trustworthy/dependable.

The above the Table 14 and Figure 14, it shows that 92\% of the total respondents trust the online customer reviews.

Table 15. Share your favorite brand's post on social media.

\begin{tabular}{cc}
\hline Share your favorite brand's post on social media & No. of respondents \\
\hline Always & 57 \\
Sometimes & 102 \\
Never & 41 \\
Total & 200 \\
\hline
\end{tabular}




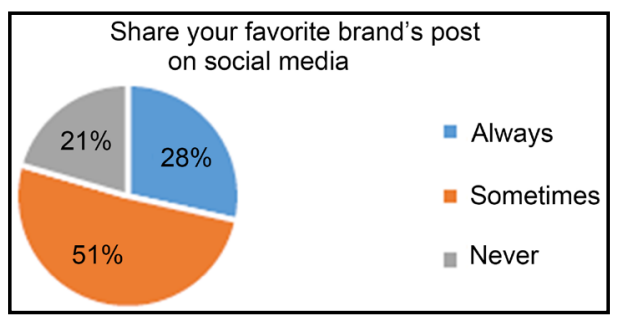

Figure 15. Share your favorite brand's post on social media.

It is inferred from the above Table 15 and Figure 15, that 51\% sometime share their favorite posts of brands on social media, $29 \%$ always share and $21 \%$ never share with friends.

Table 16. Share a content on social media, if it has.

\begin{tabular}{cc}
\hline Share a content on social media, if it has & No. of respondents \\
\hline Practical Value & 125 \\
Emotional appeal & 48 \\
Negative content & 15 \\
story & 12 \\
Total & 200 \\
\hline
\end{tabular}

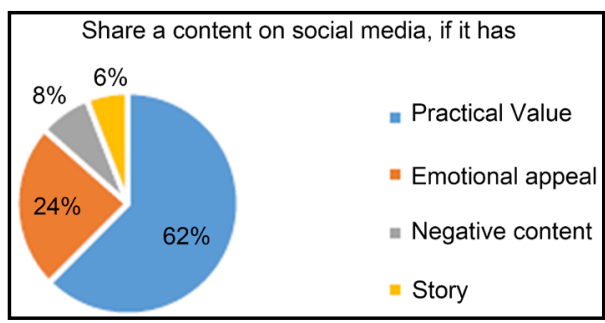

Figure 16. Share a content on social media, if it has.

From the Table 16 and Figure 16, it is inferred from the above graph that practical value of the brands content is valued by $63 \%$, Emotional appeal by $24 \%$, Negative content by $8 \%$ and Story by $6 \%$ of the total respondents.

The study tries to determine if the gender affects eWOM communication among people, based on the six motivational factors: self-expression, venting negative feelings, vengeance, concern for others, overall trust and distrust using the independent analysis of variance (t-test) statistical tool.

\section{Analysis of Gender with Self-Expression and Vengeance}

\subsection{Independent Sample T-Test}

Table 17. Group statistics.

\begin{tabular}{cccccc}
\hline & Gender & $\mathbf{N}$ & Mean & Std. deviation & Std. error mean \\
\hline \multirow{2}{*}{ Self-Expressive } & Male & 102 & 2.35 & 0.699 & 0.069 \\
& Female & 98 & 1.99 & 0.711 & 0.072 \\
\multirow{2}{*}{ Vengeance } & Male & 102 & 1.99 & 0.652 & 0.065 \\
& Female & 98 & 2.55 & 0.660 & 0.067 \\
\hline
\end{tabular}


Table 18. Independent samples test.

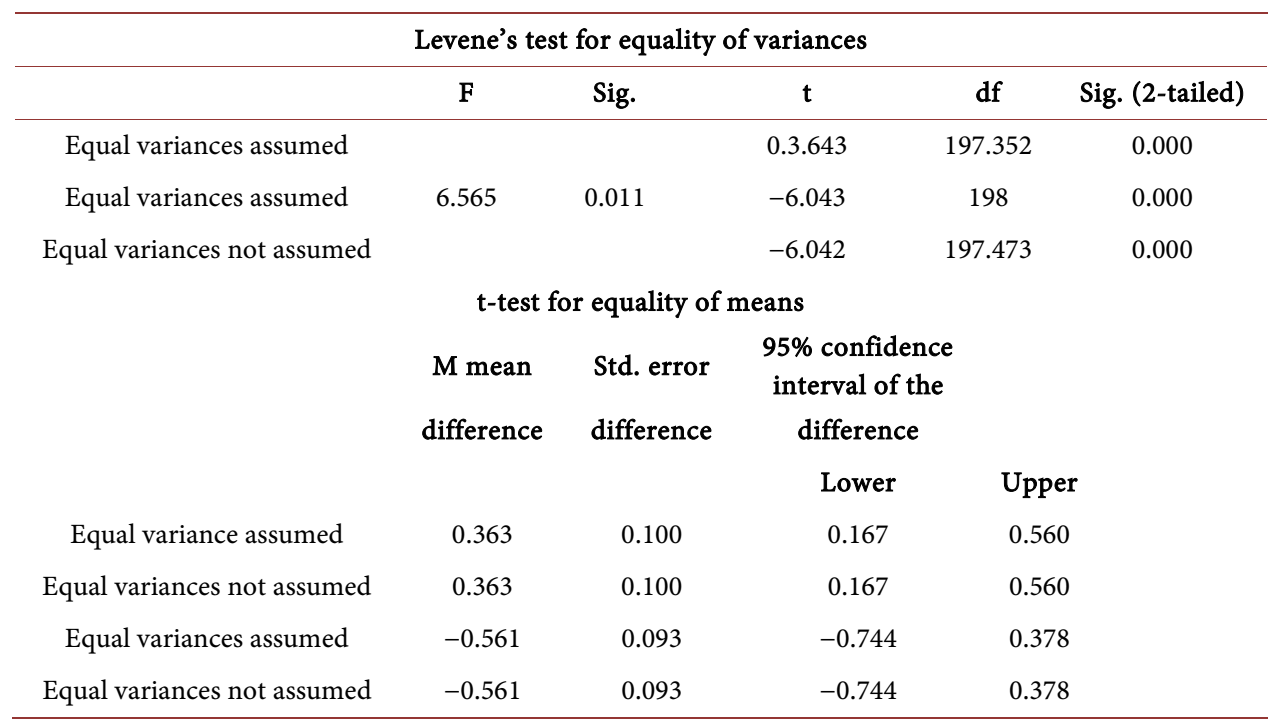

\subsubsection{Results}

- Null Hypothesis (Ho): There exists no significant relationship between gender and the motivation of self-expression.

- Alternate Hypothesis (H1): There exists significant relationship between gender and the motivation of self-expression.

\subsubsection{Independent Test Results}

As shown in the Table 18, the Sig 0.047 value is lesser than 0.05 so, reject Ho and accept H1.

- Hence the results indicated that, there exists significant relationship between gender and the motivation of self-expression.

- From the Table 17, this also indicates from the mean value of male (2.35) is greater than the mean value of female (1.99).

- So, more male respondents than female respondents like/want to express their feeling through online reviews.

\subsubsection{Hypothesis}

Men are more likely motivated by self-expression to provide eWOM than women.

\subsubsection{Results}

- Null Hypothesis (Ho): There exists no significant relationship between gender and the motivation of vengeance upon the company.

- Alternate Hypothesis (H1): There exists significant relationship between gender and the motivation of vengeance upon the company.

\subsubsection{Independent Test Results}

- As shown in the Table 18 the Sig 0.011 value is lesser than 0.05 so, reject Ho and accept $\mathrm{H} 1$.

- Hence the results indicated that, there exists significant relationship between gender 
and the motivation of vengeance upon the company.

- From the Table 17, this also indicates from the mean value of female (2.55) is greater than the mean value of male (1.99).

- So, more female respondents than male respondents are likely to seek revenge towards the company for not being satisfied with the product/service.

\subsubsection{Hypothesis}

Women are more likely motivated by vengeance upon a company to provide eWOM than men.

\subsection{Analysis of Gender with Overall Trust and Concern for Others}

Table 19. Independent sample t-test.

\begin{tabular}{cccccc}
\hline & Gender & $\mathrm{N}$ & Mean & Std. deviation & Std. error mean \\
\hline \multirow{2}{*}{ Concern for others } & Male & 102 & 1.44 & 0.654 & 0.065 \\
& Female & 98 & 1.41 & 0.623 & 0.063 \\
Overall trust & Male & 102 & 1.95 & 0.680 & 0.067 \\
& Female & 98 & 1.89 & 0.716 & 0.072 \\
\hline
\end{tabular}

Table 20. Independent samples test.

\begin{tabular}{|c|c|c|c|c|c|}
\hline \multicolumn{6}{|c|}{ Levene's test for equality of variances } \\
\hline & F & Sig. & $\mathbf{t}$ & df & $\begin{array}{c}\text { Sig. } \\
\text { (2-tailed) }\end{array}$ \\
\hline $\begin{array}{l}\text { Equal variances } \\
\text { assumed }\end{array}$ & 0.457 & 0.500 & 0.365 & 198 & 0.715 \\
\hline $\begin{array}{c}\text { Equal variances not } \\
\text { assumed }\end{array}$ & & & 0.366 & 197.989 & 0.715 \\
\hline $\begin{array}{l}\text { Equal variances } \\
\text { assumed }\end{array}$ & 1.403 & 0.238 & 0.640 & 198 & 0.523 \\
\hline $\begin{array}{c}\text { Equal variances not } \\
\text { assumed }\end{array}$ & & & 0.640 & 196.356 & 0.523 \\
\hline \multicolumn{6}{|c|}{ t-test for equality of means } \\
\hline & Mean & Std. error & $\begin{array}{l}95 \% \text { confidence interval } \\
\text { of the }\end{array}$ & & \\
\hline & difference & difference & difference & & \\
\hline & & & Lower & Upper & \\
\hline $\begin{array}{l}\text { Equal variance } \\
\text { assumed }\end{array}$ & 0.033 & 0.090 & -0.145 & 0.211 & \\
\hline $\begin{array}{c}\text { Equal variances not } \\
\text { assumed }\end{array}$ & 0.033 & 0.090 & -0.145 & 0.211 & \\
\hline $\begin{array}{l}\text { Equal variances } \\
\text { assumed }\end{array}$ & 0.063 & 0.099 & -0.132 & 0.258 & \\
\hline $\begin{array}{c}\text { Equal variances not } \\
\text { assumed }\end{array}$ & 0.063 & 0.099 & -0.132 & 0.258 & \\
\hline
\end{tabular}

\subsubsection{Results}

- Null Hypothesis (Ho): There exists no significant relationship between gender and the motivation of concern for others.

- Alternate Hypothesis (H1): There exists significant relationship between gender and the motivation of concern for others. 


\subsubsection{Independent Test Results}

- Based on the standard deviation of Male 0.654 and female 0.623 as given in Table 19 and as shown in the Table 20 the Sig 0.500 value is greater than 0.05 so, accept Ho and reject $\mathrm{H} 1$.

- Hence the results indicated that, there exists no significant relationship between gender and the motivation of concern for others.

\subsubsection{Results}

- Null Hypothesis (Ho): There exists no significant relationship between gender and the motivation of overall trust.

- Alternate Hypothesis (H1): There exists significant relationship between gender and the motivation of overall trust.

\subsubsection{Independent Test Results}

- As shown in the Table 20 the Sig 0.238 value is greater than 0.05 so, accept Ho and reject $\mathrm{H} 1$.

- Hence the results indicated that, there exists no significant relationship between gender and the motivation of overall trust.

\subsection{Analysis of Gender with Impact of Positive and Negative Reviews When Comes to Buying Choice}

\subsubsection{Independent Sample T-Test}

Table 21. Group Statistics.

\begin{tabular}{cccccc}
\hline & Gender & N & Mean & Std. deviation & Std. error mean \\
\hline \multirow{2}{*}{ Positive review } & Male & 102 & 1.13 & 0.414 & 0.041 \\
& Female & 98 & 1.19 & 0.568 & 0.057 \\
\multirow{2}{*}{ Negative review } & Male & 102 & 1.08 & 0.305 & 0.030 \\
& Female & 98 & 1.15 & 0.505 & 0.051 \\
\hline
\end{tabular}

Table 22. Independent samples test.

\begin{tabular}{|c|c|c|c|c|c|}
\hline \multicolumn{6}{|c|}{ Levene's test for equality of variances } \\
\hline & F & Sig. & $\mathrm{t}$ & df & Sig. (2-tailed) \\
\hline $\begin{array}{l}\text { Equal variances } \\
\text { assumed }\end{array}$ & 4.086 & 0.045 & -0.947 & 198 & 0.345 \\
\hline $\begin{array}{l}\text { Equal variances } \\
\text { assumed }\end{array}$ & 7.079 & 0.08 & -1.272 & 198 & 0.205 \\
\hline Equal variances not assumed & & & -1.260 & 158.185 & 0.210 \\
\hline & $\begin{array}{c}\text { Mean } \\
\text { difference }\end{array}$ & $\begin{array}{l}\text { Std. error } \\
\text { difference }\end{array}$ & $\begin{array}{l}95 \% \text { confidence interval of the } \\
\text { difference }\end{array}$ & & \\
\hline & & & Lower & Upper & \\
\hline $\begin{array}{l}\text { Equal variance } \\
\text { assumed }\end{array}$ & -0.066 & 0.070 & -0.205 & 0.072 & \\
\hline Equal variances not assumed & -0.066 & 0.071 & -0.206 & 0.073 & \\
\hline
\end{tabular}




\subsubsection{Results}

- Null Hypothesis (Ho): There exists no significant relationship between gender and the positive product reviews.

- Alternate Hypothesis (H1): There exists significant relationship between gender and the positive product reviews.

\subsubsection{Independent Test Results}

- As Shown in Table 22 the Sig 0.045 value is lesser than 0.05 so, reject Ho and accept $\mathrm{H} 1$.

- Hence the results indicated that, there exists significant relationship between gender and the positive product reviews.

- As shown in Table 21 this also indicates from the mean value of female (1.19) is greater than the mean value of male (1.13).

- So, more female respondents than male respondents consider positive online reviews before making a purchase choice.

\subsubsection{Hypothesis}

Women are more likely to consider positive online reviews before purchase than men.

\subsubsection{Results}

- Null Hypothesis (Ho): There exists no significant relationship between gender and the negative product reviews.

- Alternate Hypothesis (H1): There exists significant relationship between gender and the negative product reviews.

\subsubsection{Independent Test Results}

- As shown in the Table 22, the Sig 0.08 value is greater than 0.05 so, accept Ho and reject $\mathrm{H} 1$.

- Hence the results indicated that, there exists no significant relationship between gender and the negative product reviews.

\subsection{Analysis of Different Age Group and Impact of Reviews Presented Online}

Table 23. Age ${ }^{\star}$ purchase choice cross tabulation

\begin{tabular}{cccccc}
\hline Count & \multicolumn{3}{c}{ Product rating } & Total \\
\hline & & 1 & 2 & 3 & \\
$20-25$ yrs & 27 & 11 & 2 & 40 \\
$26-30$ yrs & 38 & 11 & 3 & 52 \\
Age & 29 & 11 & 4 & 44 \\
& $36-35$ yrs & 10 & 2 & 1 & 13 \\
& Above 40 yrs & 17 & 10 & 2 & 29 \\
& Below 20 yrs & 14 & 7 & 1 & 22 \\
\hline
\end{tabular}


Table 24. ChI-square tests.

\begin{tabular}{cccc}
\hline & Value & df & $\begin{array}{c}\text { Asymptotic } \\
\text { significance (2-sided) }\end{array}$ \\
\hline Pearson chi-square & $3.789 \mathrm{a}$ & 10 & 0.956 \\
Likelihood ratio & 3.803 & 10 & 0.956 \\
N of valid cases & 200 & & \\
\hline
\end{tabular}

\subsubsection{Results}

- Null Hypothesis (Ho): There exists no significant relationship between age groups and the reviews present online.

- Alternate Hypothesis (H1): There exists significant relationship between age groups and the reviews present online.

\subsubsection{Chi-Square Test Results}

- Chi-square test results based on the data given in Table 23 as age \& purchase choice cross-tabulation and s shown in the Table 24 the Sig 0.956 value is greater than 0.05 so, accept Ho and reject $\mathrm{H} 1$.

- Hence the results indicated that, there exists no significant relationship between age groups and the reviews present online.

- Based on the data given in Table 25 as age \& product rating cross-tabulation and as shown in the Table 26 the Sig 0.194 value is greater than 0.05 so, accept Ho and reject $\mathrm{H} 1$.

\subsubsection{Results}

- Null Hypothesis (Ho): There exists no significant relationship between age groups and the product ratings online.

- Alternate Hypothesis (H1): There exists significant relationship between age groups and the product ratings online.

Table 25. Age ${ }^{\star}$ product rating cross tabulation.

\begin{tabular}{|c|c|c|c|c|c|}
\hline \multirow[t]{2}{*}{ Count } & & \multicolumn{3}{|c|}{ Product rating } & \multirow[t]{2}{*}{ Total } \\
\hline & & 1 & 2 & 3 & \\
\hline & $20-25 \mathrm{yrs}$ & 13 & 26 & 1 & \\
\hline & $26-30$ yrs & 23 & 28 & 1 & \\
\hline & $31-35$ yrs & 25 & 19 & 0 & \\
\hline \multirow[t]{4}{*}{ Age } & $36-40$ yrs & 8 & 5 & 0 & \\
\hline & Above 40 yrs & 15 & 14 & 0 & \\
\hline & Below 20 yrs & 9 & 11 & 2 & \\
\hline & Total & 93 & 103 & 4 & 200 \\
\hline
\end{tabular}


Table 26. Chi-square tests.

\begin{tabular}{rccc}
\hline & Value & df & $\begin{array}{c}\text { Asymptotic } \\
\text { significance (2-sided) }\end{array}$ \\
\hline Pearson chi-square & $13.563 \mathrm{a}$ & 10 & 0.194 \\
Likelihood ratio & 12.728 & 10 & 0.239 \\
N of valid cases & 200 & & \\
\hline
\end{tabular}

\subsubsection{Chi-Square Test Results}

- As shown in the Table 26 the Sig 0.194 value is greater than 0.05 so, accept Ho and reject $\mathrm{H} 1$.

- Hence the results indicated that, there exists no significant relationship between age groups and the product ratings online.

\section{Findings}

- There exists significant difference between gender and the self-expression and vengeance where, Men are more likely motivated by self-expression to provide eWOM than women and Women are more likely motivated by vengeance upon a company to provide eWOM than men.

- There exists no significant relationship between gender and the motivation of concern for others and overall trust.

- There exists no significant relationship between age groups and the product.

- significant relationship between gender and the negative product reviews.

\section{Interpretations}

- Consumers are not a homogeneous group as far as their eWOM motivational systems. According to the presence of different motivation segments, strategies can be built for encouraging and increasing eWOM participation with particular segments in mind.

- Advertisers who target both men and ladies can grow more pertinent arrangements to pull in purchasers of both sexual orientations, however maybe in various ways. Focus could be given on how to solve problems received in form ratings online. All age groups have similar opinion about the product ratings present online which they browse before a purchase.

- There exists no significant relationship between age groups and the reviews present online. All age groups have similar opinion about the reviews present online which they browse before a purchase.

- Women are more likely to consider positive online reviews before purchase than men. Positive reviews have an impact on purchase decision while negative reviews don't and there exists no of eWOM, rather than simply being a forum for complaints. This could also depict the marketer as more consumer-oriented and responsive to consumers' needs which would appeal to consumers of both genders.

- Marketers could design its eWOM platform to include a posted response from the 
company directly after a complaint that helps to remedy the consumers' situation. This feature could help to reduce the desire to seek revenge on a company on the part of its female consumers while providing a way to improve and nurture its relationships with its male consumers.

- The platform should be designed so that the customers can express themselves, communicate, create their own identities, and develop a association with the brand and others. Positive interactions on these platforms could help develop brand loyalty among customers, which, ultimately, benefits the brand and other consumers seeking guidance in their purchases.

- Listening is key in picking up acceptance among more youthful clients These clients aren't simply trying to "like" a brand on Facebook, they should be interactive and speaking with different clients. Two-way correspondence between the brand and the customers is an unquestionable requirement to create connections.

\section{Conclusion}

- The purpose of this study was to examine the perceived influence of electronic word-of-mouth (eWOM) when consumed across the online platforms with respect to gender and the influence on their buying choice. An online survey was administered through Google forms and get response to a sample of 1000 respondents.

- Independent sample T-test, paired sample test and Chi-squares tests were used to test the hypotheses from the data.

- The first purpose of this study was to examine if different genders affect consumers' communication on eWOM, and if these consumers have different motivations and expectations for this communication vehicle. Specifically, male and female were compared. Using a sample of 200.

- The results suggest that gender differences will have impact on self-expression and vengeance upon company. No significant relationship was found between gender and overall trust, venting negative feelings, trust, and distrust separately.

- The second purpose of this study was to examine the influence of eWOM whether consumers rely on information/product ratings from others in making purchase decision/ buying choice.

- The consumers appeared to consider the positive online reviews when compared to the negative online reviews. The product/service ratings did not have any significant relationship to the age group of respondents.

- Consumer's channels surf amongst brick and-mortar stores and websites; they are nowadays progressively looking for digital content. Organizations can make credibility through product reviews/ratings on sites.

- For information seekers, the source of data is no more restricted to a little arrangement of individuals who traditionally have similar experience and backgrounds, however rather the data pool comprises of feelings and reviews from a wide assortment of individuals, with both direct and indirect and also positive and negative experience with a given product/service (Cheung and Lee, 2012). 
- Generally, this paper gives a structure to future study in the field of eWOM. As consumers are always being offered new innovation, new platforms will be created/altered to address their issues. Facebook, Twitter, web journals, and so forth are gatherings that have been seen positively and negatively now and again.

- It is up to the brand/company to look into their customer and build up a platform that addresses their issues.

\section{Limitations}

- The information of respondents was from just particular areas and thus utilized a helpful convenient sampling. The outcomes could be more appropriate to bigger population if the sample was extended.

- This study permits conclusion at a aggregate level of eWOM on online platforms, making it hard to identify eWOM with particular kind of product/services. (For Instance: Electronic products, Apparel \& Fashion, Automobile, Home Furnishings and so forth.)

- The future research could recreate the study by investigating consumers' online eWOM consumed on specific type of social media networks. For instance, "Online reviews/comments posted on Facebook, LinkedIn, Twitter, Snapchat, Vine or Google+".

\section{References}

[1] Kaplan, A.M. and Haenlein, M. (2010) Users of the World, Unite! The Challenges and Opportunities of Social Media. Business Horizons, 53, 59-68. http://dx.doi.org/10.1016/j.bushor.2009.09.003

[2] Hennig-Thurau, T. and Walsh, G. (2003) Electronic Word-of-Mouth: Motives for and Consequences of Reading Customer Articulations on the Internet. International Journal of Electronic Commerce, 8, 51-74.

[3] Wang, Y. and Rodgers, S. (2011) Electronic Word of Mouth and Consumer Generated Content: From Concept to Application, Missouri School of Journalism, USA.

[4] Erkan, I. (2014) "Vine": Do You Miss It? Electronic Word of Mouth on the Social Networking Site, Vine. International Journal of Business and Information, 9, 461-473.

[5] Facebook Statistics, Stats, \& Facts for 2015. http://www.digitalbuzzblog.com

[6] Qiu, L.Y., Pang, J. and Lim, K.H. (2012) Effects of Conflicting Aggregated Rating on eWOM Review Credibility and Diagnosticity. Journal Decision Support Systems Archive, 54, 631-643.

[7] Bullas (2012) Significant Social Media Facts, Figures and Statistics Plus 7 Info Graphics.

[8] Anderson, Eric Social Media Marketing, Springer-Verlag Publications, 2, 48-50.

[9] Lehmann, W.S. (2015) The Influence of Electronic Word-of-Mouth (eWOM) on College Search and Choice. Open Access Dissertations, Paper 1378.

[10] Higgins, E.T. and Silberman, I. (1998) Development of Regulatory Focus: Promotion and Prevention as Ways of Living. In: Heckhausen, J. and Dweck, C.S., Eds., Motivation and Self-Regulation across the Life Span, Cambridge University Press, New York, 78-113. http://dx.doi.org/10.1017/CBO9780511527869.005

[11] Cheunga, C.M.K. and Thadani, D.R. (2012) The Impact of Electronic Word-of-Mouth 
Communication: A Literature Analysis and Integrative Model. Decision Support Systems, 54, 461-470. http://dx.doi.org/10.1016/j.dss.2012.06.008

[12] Ong, W.J. (1981) Fighting for Life: Contest, Sexuality, and Consciousness. Cornell University Press, Cornell.

[13] Tannen, D. (1990) You Just Don't Understand: Women and Men in Conversation. William Morrow \& Co Inc., USA.

[14] Kothari, C.R. (1990) Research Methodology: Methods and Techniques Wishwa. Prakashan, New Delhi.

[15] Slesinger, D. and Stephenson, M. (1930) The Encyclopaedia of Social Sciences. Vol. IX, MacMillan Publications.

\section{Submit or recommend next manuscript to SCIRP and we will provide best service} for you:

Accepting pre-submission inquiries through Email, Facebook, LinkedIn, Twitter, etc. A wide selection of journals (inclusive of 9 subjects, more than 200 journals)

Providing 24-hour high-quality service

User-friendly online submission system

Fair and swift peer-review system

Efficient typesetting and proofreading procedure

Display of the result of downloads and visits, as well as the number of cited articles Maximum dissemination of your research work

Submit your manuscript at: http://papersubmission.scirp.org/

Or contact iim@scirp.org 